\title{
Past and present variability in leaf length of evergreen members of Nothofagus subgenus Lophozonia related to ecology and population dynamics
}

Gregory J. Jordan and Robert S. Hill

Department of Plant Science

University of Tasmania

Box 252C, Hobart

Tasmania 7001, Australia

\section{Summary}

The lengths of fossil leaves of Nothofagus cunninghamii, and of closely related fossil species from sediments older than the Middle Pleistocene showed greater variation than fossil leaves from younger sediments and extant leaves from modern sediment samples and forest floor litter. Leaf sizes of samples of the other two extant evergreen species of Nothofagus subgenus Lophozonia, $N$. moorei and $N$. menziesii, were no more variable than modern $N$. cunninghamii. Leaf lengths of modern and Middle-Late Pleistocene N. cunninghamii and of modern $N$. menziesii were more or less unimodal in distribution, whereas the leaves of $N$. moorei follow bimodal distributions, and leaves from the Early Pleistocene Regatta Point and the Oligocene Little Rapid River sediments tended to be bimodal and highly variable. Leaf lengths from the Oligo-Miocene Monpeelyata sediments were also highly variable, but the sample size was too small to determine if they follow bimodal distributions. The bimodality and high variability in the older sites are unlikely to have been due to taphonomic processes. Thus, within population variability appears to have declined during the Late Tertiary-Early Pleistocene, although the presence of cryptic species in the fossil record could also explain the results. Both a decline in variability within species, and the extinction of Nothofagus species, are consistent with a well documented Late Cainozoic decline in rainforest diversity in Tasmania.

Log transformed leaf lengths of modern forest floor litter samples of $N$. cunninghamii were strongly correlated with climatic parameters, particularly summer temperature, suggesting that this parameter is a strong determinant of leaf size in $N$. cunninghamii. Changes in $N$. cunninghamii leaf lengths within Middle Pleistocene sediments were associated with floristic changes interpreted as transitions in glacial/interglacial cycles, but these changes were small compared with changes predicted from climatic correlation of extant samples, probably because of limited genetic variability in local populations at the time of deposition.

Additional Keywords. palaeoecology, physiognomy, taphonomy, climate, diversity. 


\section{Introduction}

There is empirical evidence that leaf size increases with temperature when water is not limiting. Average leaf length and width of whole floras (e.g. Wolfe \& Upchurch 1987; Christophel \& Greenwood 1989), and often of species within genera (e.g. Hill \& Read 1987), tend to increase with temperature. The relationship of leaf length to temperature within species is less well known. Leaf width, at least, also tends to increase with precipitation below about $1000 \mathrm{~mm}$ per annum but there tends to be little change at higher precipitations (Givnish 1987). Webb (1959) used leaf size for primary divisions in his classification of Australian rainforest types. These divisions appear to be determined by temperature, through altitude or latitude differences, if rainfall is sufficient (Webb 1968).

The reasons why leaf size varies with temperature are not known. Part of the variation is likely to be genetically controlled with plastic phenotypic variation producing the remainder. Givnish (1984) suggested that the variation under genetic control is largely determined by selection for trade-offs optimising production.

There have been few studies of the relationships of past plant phenotypes to ecological differences between populations of species, or between closely related species, perhaps partly because most studies of fossil population dynamics are based on pollen, and it is difficult to associate variation in pollen morphology with environmental change. Relatively high variability within extant populations is often caused by recent mixing of genotypes (Endler 1977). However, neither the degree of variability in leaf size within fossil populations, nor the effects of taphonomy on this variability are well studied. Taphonomy probably affects variability, since leaves may enter sediments from several sources and sorting may restrict the range of leaf sizes and often favours smaller leaves (e.g. Spicer 1981).

The period since the Late Oligocene (periods according to Harland et al. 1990) has been critical to the formation of modern vegetation in Tasmania, since the Tertiary floras with diverse mesothermal rainforest components (Carpenter, Hill \& Jordan 1994) were transformed into depauperate rainforest and rich sclerophyll floras by the Late Pleistocene (Hope 1994; Macphail et al. 1994). This probably occurred through a series of steps, notably during the Late Pliocene and the Early and Middle Pleistocene (Macphail, Jordan \& Hill $1993 b$ ). These vegetation changes have been attributed to climatic effects (e.g. Kershaw 1988; Macphail \& Truswell 1989; Kershaw et al. 1991), in particular drying and cooling through the late Tertiary, and major climatic fluctuations (Shackleton \& Opdyke 1973, Shackleton 1982) and intermittent glacial activity during the Pleistocene (Fitzsimons and Colhoun 1991).

The evergreen species of Nothofagus subgenus Lophozonia (subgeneric classification according to Hill \& Read 1991; Hill \& Jordan 1993) are ideally suited to studies of the past and present responses to climate of species or small groups of species. Leaf fossils of this group are readily and precisely identified, and are abundant in some Tertiary and Pleistocene sediments (Hill 1983b; Hill \& Macphail 1983; Pole et al. 1993; Hill 1991). Taphonomic biases in leaf size are likely to be small since the leaves are robust. The fossil species were almost certainly canopy trees or shrubs of wet climates (Hill 1991) and evergreen, since the leaves have thick cuticles like those of extant evergreen species, and unlike those of any extant deciduous species of Nothofagus, Fagaceae, or Betulaceae. The effects of precipitation, shading and deciduousness are, therefore, unlikely to obscure the relationships of leaf size with temperature.

There are indications of differences between modern and fossil populations of Nothofagus subgenus Lophozonia in Tasmania. Leaves in the Early Pleistocene Regatta Point sediments in western Tasmania are highly variable, and appear to show bimodal distributions in leaf size (Jordan 1992). Hill (1983a) observed that most leaves of Tertiary fossils of Nothofagus from Tasmania were larger than leaves of extant $N$. cunninghamii. He also suggested that the leaves from the Pioneer sediments were more variable than those of extant $N$. cunninghamii. However that study used herbarium specimens, which are not unbiased samples, and did not consider the effects of taphonomic processes on leaf size and variability. 
Hill (1991) confirmed that the fossils used by Hill (1983a) and the present study are from Nothofagus subgenus Lophozonia and are close to the ancestral lineage of $N$. cunninghamii.

This study, therefore, investigates fossil and extant Nothofagus subgenus Lophozonia leaf lengths in an attempt to identify changes in population structure since the Late Tertiary, and discusses the relationships of these changes to major changes in vegetation during this period. Leaf length distributions of populations of the three extant evergreen species, $N$.

cunninghamii from Tasmania and southern Victoria, N. moorei from northern New South Wales, and N. menziesii from New Zealand (Fig. 1), are studied to determine whether they are consistent with the fossils. Taphonomic processes and the relationship of extant climate to leaf size are also studied, mainly in N. cunninghamii, to determine whether the changes in variability in leaf size through the Cainozoic could be explained by contributions from different populations within regions, and to assist in the ecological interpretation of the changes in leaf size.
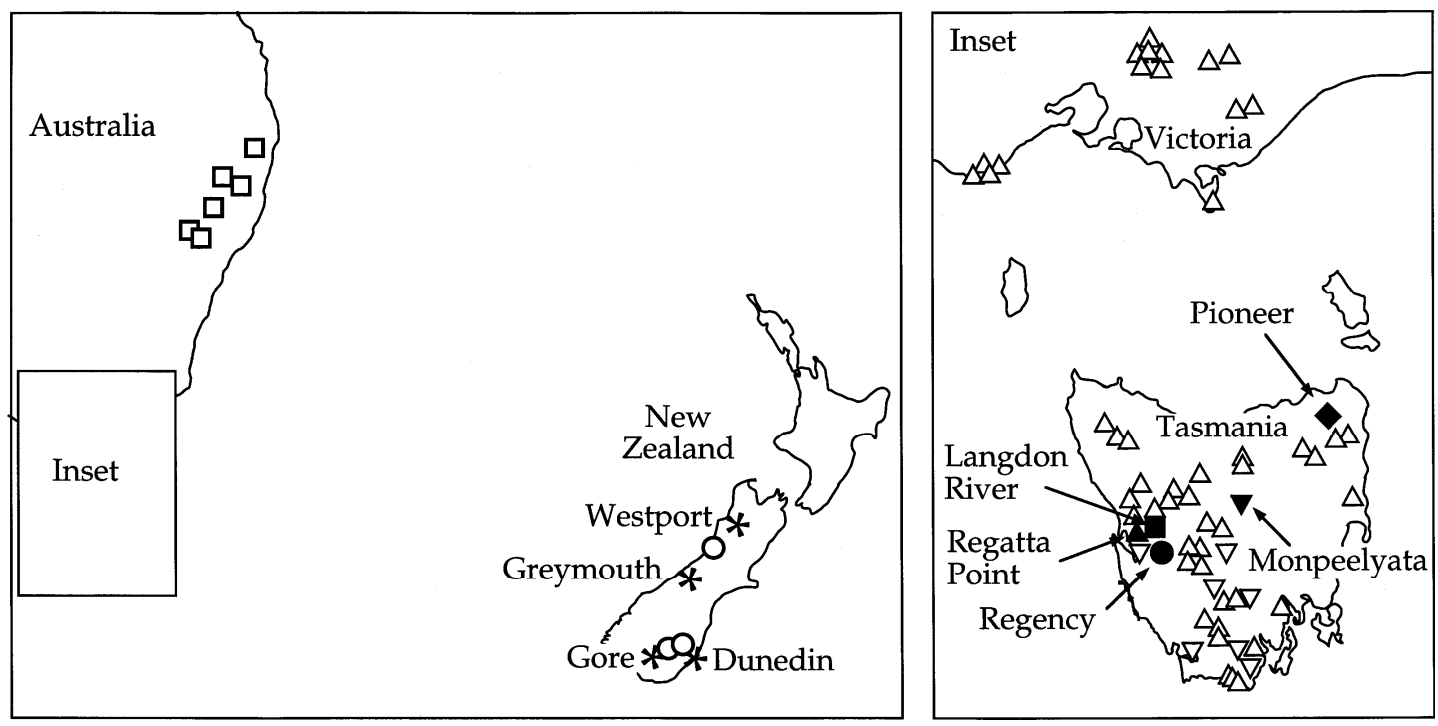

Figure 1. Locations of litter sample sites (open triangles for Nothofagus cunninghamii, open squares for Nothofagus moorei, and open circles for Nothofagus menziesii), fossil sites (black symbols) and taphonomic sites (open inverted triangles).

\section{Materials and Methods}

Fossil leaves and localities

Fossil leaves were studied from five localities in Tasmania: Pioneer in the north-east, Monpeelyata in central Tasmania, and Langdon River, Regency and Regatta Point in the west (Fig. 1). These regions have cool perhumid climates (Gentilli 1972) and areas below about $900 \mathrm{~m}$ a.s.l. are climatically suited to the growth of $N$. cunninghamii dominated cool temperate rainforest, except perhaps near Pioneer (Read \& Busby 1990). The sites were below $300 \mathrm{~m}$ altitude, except Monpeelyata (920 m a.s.1.). Leaves of $N$. maidenii (Dean) Pole, Hill, Green \& Macphail (as N. johnstonii Hill) from one lens in the Late Oligocene/Early Miocene (Macphail et al. 1994) Pioneer sediments were studied. The micro- and macro-fossil floras in this lens indicated that both the conifer and the rainforest angiosperm diversity were clearly higher than in any modern vegetation in Tasmania (Hill and Macphail 1983).

Leaves of $N$. microphylla Hill were studied from the floristically and texturally homogeneous Late Oligocene/Early Miocene (Macphail et al. 1991) Monpeelyata sediments. The floristics and physiognomy of the micro- and macrofossil assemblages in this lens were consistent with a cool climate, but included significantly more conifer genera than modern Tasmania (Macphail et al. 1991). 
Fossil leaves which were individually consistent with $N$. cunninghamii and clearly distinct from any other extant species (Hill 1991; Jordan 1992) were studied from three Pleistocene sites (Regatta Point, Regency and Langdon River; Hill \& Macphail 1985; Colhoun et al. 1989; Fitzsimons et al. 1990; Jordan 1992; Macphail et al. 1993b).

The leaves from Regatta Point were extracted from mudstone clasts up to $1.2 \mathrm{~m}$ maximum diameter, transported from an unknown source and deposited among Middle-Late Pleistocene gravels (Hill \& Macphail 1985; Macphail et al. 1993 b). The relative ages of the different clasts and of the strata within each clasts is unknown (Macphail et al. 1993b). The leaves were separated into two groups, RPU1 and RPU2. RPU2 came from a single clast containing three thin, richly fossiliferous strata (less than $1 \mathrm{~cm}$ thick). Leaves from each of these strata were treated separately and will be referred to as RPU $25 \mathrm{~cm}, 17 \mathrm{~cm}$ and $26 \mathrm{~cm}$, respectively. Fossils from several other clasts, including one described by Hill and Macphail (1985), were pooled and collectively referred to as RPU1, since no single stratum in any of these contained enough Nothofagus leaves for quantitative assessment. The fossil assemblages from these clasts were floristically similar to each other, and distinct from RPU2, but both implied that the local riparian vegetation included mixtures of taxa which are now found in widely different environments, including modern cool temperate rainforest, warm temperate rainforest, and alpine and subalpine vegetation (Jordan 1992, Macphail et al. $1993 b$ ). The rainforest floras were more diverse than any extant in Tasmania (Jordan 1992; Macphail et al. 1993b). The fossil floras differed mainly in that RPU1 contained more fossils of sclerophyllous taxa and charcoal, and fewer fossils of rainforest taxa than RPU2.

The Regency Formation is made up of richly organic sediments overlying Early Pleistocene glacial till (Fitzsimons et al. 1990). The micro- and macrofossil floras imply a transition from subalpine rainforest/woodland to lowland mixed temperate rainforest/sclerophyll forest, which has been interpreted as showing a transition from late glacial to interglacial conditions (Fitzsimons et al. 1990, Jordan 1992).

The fossil Nothofagus leaves from Langdon River used here are from the middle of zone three from the Upper Site of Colhoun et al. (1989), which these authors considered to reflect interglacial conditions, with cool temperate forest.

The Regatta Point sediments are likely to be Early Pleistocene, but a Middle Pleistocene age is possible (Macphail et al. 1993b). Although Fitzsimons et al. (1990) and Fitzsimons \& Colhoun (1991) considered that the Regency sediments were deposited during the Early Pleistocene or earliest Middle Pleistocene, a Middle Pleistocene age is more likely considering the weathering of erratics in the underlying glacial till (E. A. Colhoun pers. comm.). The Langdon River sediments were deposited in the Last Interglacial or earlier (Colhoun et al. 1989) and contain fossil floras consistent with the latter part of the Middle Pleistocene (Colhoun et al. 1989). The Regatta Point sediments are almost certainly older than the Regency sediments, which are likely to be older than the Langdon River sediments, since several regionally extinct taxa occur in the Regatta Point sediments, only two occur in the Regency sediments and none in the Langdon River sediments (Colhoun et al. 1989; Fitzsimons et al. 1990; Macphail et al. 1993b).

\section{Litter Sample Sites}

The fossil leaves described above are compared with leaves from litter collected beneath Nothofagus-dominated forest canopies. Litter was used instead of living leaves, because both fossilisation and formation of leaf litter represent accumulation of dead leaves and because it is difficult to sample living foliage consistently and representatively. We assumed that leaf sizes in aquatic sediments and in forest floor litter have similar responses to environmental variation. This is likely since both tend to be strongly dominated by canopy/sun leaves (Ferguson 1985; Burnham 1989).

Litter samples were collected widely across the extant range of evergreen members of Nothofagus subgenus Lophozonia with six litter samples of $N$. moorei, 15 samples of $N$. cunninghamii from Victoria and 39 from Tasmania, and three samples of $N$. menziesii from 
New Zealand (Fig. 1). Each sample was a composite of at least five $0.01 \mathrm{~m}^{2}$ plots randomly placed in parts of a $1000 \mathrm{~m}^{2}$ area of forest floor containing Nothofagus leaves.

\section{Taphonomic Sites}

Lengths of $N$. cunninghamii leaves from sediments and from litter underneath the source vegetation of the leaves in these sediments were measured. This analysis assumes that biases in leaf size between fossils and extant forest floor litter fall within bounds which can be estimated by comparing the lengths of leaves from forest floor litter and leaves in sediments. This analysis therefore ignores possible biases caused after deposition, including the effects of extraction of the fossils. These effects are unlikely to cause large biases in leaf length because of the robust nature of the leaves, their excellent preservation, and the use of the most gentle of extraction methods (usually maceration in HF, or no maceration at all). Eight modern sedimentary sites were chosen to cover a wide range of taphonomic conditions, including rivers, lakes and drift samples, differences in distance of transport and inflow rates, and a wide range of leaf sizes (Fig. 1; Table 1).

Table 1. Details of taphonomic sites. The locations of sites where Nothofagus cunninghamii leaves from aquatic sediments were compared with leaves from forest floor litter, the numbers of leaves measured, the type of aquatic sediment and the possible ranges in distances and rates of transport from their sources to the sediments are given.

\begin{tabular}{lcccccccc} 
Site & $\begin{array}{c}\text { Latitude } \\
(\mathrm{S})\end{array}$ & $\begin{array}{c}\text { Longitude } \\
(\mathrm{E})\end{array}$ & $\begin{array}{c}\text { Altitude } \\
(\mathrm{m})\end{array}$ & Type & \multicolumn{2}{c}{$\begin{array}{c}\text {--- Transport ---- } \\
\text { Distance }\end{array}$} & $\begin{array}{c}\text { Number of leaves } \\
\text { Inflow }\end{array}$ & $\begin{array}{c}\text { Forest } \\
\text { Sediment }\end{array}$ \\
& & & & & & & & \\
Lake Dobson & $42^{\circ} 41^{\prime}$ & $146^{\circ} 35^{\prime}$ & 1030 & lake & $<1 \mathrm{~km}$ & rapid & 90 & 438 \\
Hastings & $43^{\circ} 22^{\prime}$ & $146^{\circ} 51^{\prime}$ & 390 & lake & $<50 \mathrm{~m}$ & minimal & 166 & 153 \\
Shirleys Pool & $42^{\circ} 13^{\prime}$ & $146^{\circ} 03^{\prime}$ & 530 & lake & $<200 \mathrm{~m}$ & medium & 119 & 64 \\
Macquarie Harbour & $42^{\circ} 19^{\prime}$ & $145^{\circ} 25^{\prime}$ & 0 & drift & $>2 \mathrm{~km}$ & medium & 67 & 149 \\
Old River & $43^{\circ} 19^{\prime}$ & $146^{\circ} 14^{\prime}$ & 10 & river & about $2 \mathrm{~km}$ & medium & 64 & 106 \\
Vale River & $41^{\circ} 37^{\prime}$ & $145^{\circ} 47^{\prime}$ & 250 & river & 0 to $>10 \mathrm{~km}$ & medium & 60 & 50 \\
Russell Falls & $42^{\circ} 41^{\prime}$ & $146^{\circ} 42^{\prime}$ & 170 & river & 0 to $5 \mathrm{~km}$ & rapid & 58 & 59 \\
Farmhouse Creek & $43^{\circ} 15^{\prime}$ & $146^{\circ} 38^{\prime}$ & 360 & river & $>200 \mathrm{~m}$ & rapid & 122 & 161 \\
\hline
\end{tabular}

\section{Leaf Morphometrics and Statistical Methods}

The lengths of all measurable leaves recovered from Monpeelyata (48 leaves), Pioneer (51 leaves), RPU1 (289 leaves), RPU2 (>100 leaves from each leaf rich layer), and Langdon River (between 16 and 166 leaves per $10 \mathrm{~cm}$ layer) were measured. At least 50 leaves were measured from each $10 \mathrm{~cm}$ length of core of the Regency sediments, except the poorly preserved 0 and $40 \mathrm{~cm}$ layers (10 and 33 leaves respectively). The sediments from the 30-80 $\mathrm{cm}$ strata had higher organic contents than those from $20 \mathrm{~cm}$ and above (Fitzsimons et al. 1990) suggesting some change in depositional environment.

Each modern sample was subdivided, by repeatedly splitting the samples into equal halves, until a small subsample containing at least 30 leaves was produced. The lengths of all measurable Nothofagus leaves in this subsample were measured. The number of $N$. cunninghamii leaves in the Lake Dobson samples varied greatly. Only 24 out of the 156 samples contained enough leaves, so the samples was biased towards sites of heavy sedimentation of $N$. cunninghamii leaves. However, fossil sites which contain enough measurable leaves must also have been sites of heavy sedimentation.

$\log _{10}$ transformed leaf lengths were used for all analyses because this transformation optimised the normality and homogeneity of variance assumptions of all the analyses for extant $N$. cunninghamii, and is appropriate for analysis of many linear measures of living structures (Sokal \& Rohlf 1981).

The transformed leaf lengths of representative modern and fossil samples, except Monpeelyata, were grouped into $0.05 \log _{10} \mathrm{~mm}$ classes and optimal combinations of normal distributions and goodness of fit $\mathrm{c}^{2}$ statistics were estimated using maximum likelihood 
methods (MacDonald \& Green 1988). The Monpeelyata data were grouped into $0.1 \log _{10} \mathrm{~mm}$ classes because of low numbers and high variability. The means, standard deviations and proportions of the total of each component distribution were not constrained. Distributions were considered to be unimodal unless the reduction in goodness of fit $\mathrm{c}^{2}$ associated with fitting two normal distributions instead of one was significant (MacDonald \& Green 1988).

Transformed lengths of leaves from modern sediments were compared with those of the source vegetation litter by analysis of variance for each of the sites.

Sixteen climatic parameters describing seasonal and annual precipitation and temperature were estimated for each of the N. cunninghamii and N. moorei sites using BIOCLIM (e.g. Busby 1988). These climatic parameters were related to the sample means of transformed leaf length with multiple regression, stepwise regression and normal regression using SAS (SAS Institute 1988). All regressions were weighted with the inverses of the variances of the means which compensates for differences in the reliabilities of the estimates of the sample means (SAS Institute 1988). Tests for curvature in the regressions were made using normal probability plots, and fitting quadratic regressions. Estimates of the mean temperature of the warmest quarter were calculated for the $N$. menziesii sites using interpolations between climatic averages for permanent stations at Greymouth, Westport Airport, Dunedin and Gore (Fig. 1; New Zealand Meteorological Service 1963-1985) allowing for a lapse rate of $0.65^{\circ} \mathrm{C}$ $100 \mathrm{~m}^{-1}$ (derived from BIOCLIM estimates at similar latitudes in Tasmania).

\section{Results}

Analysis of distributions of leaf lengths of extant samples

Figure 2 shows the relationship of the means of transformed leaf length to their standard deviations for extant $N$. cunninghamii, N. menziesii and N. moorei and for Nothofagus leaves from the Regatta Point, Langdon River and Regency sediments. The standard deviations of the samples of the other extant species were consistent with the critical ranges shown for $N$. cunninghamii (Fig. 2), which are therefore inferred to be the normal ranges in litter for extant evergreen Nothofagus subgenus Lophozonia.

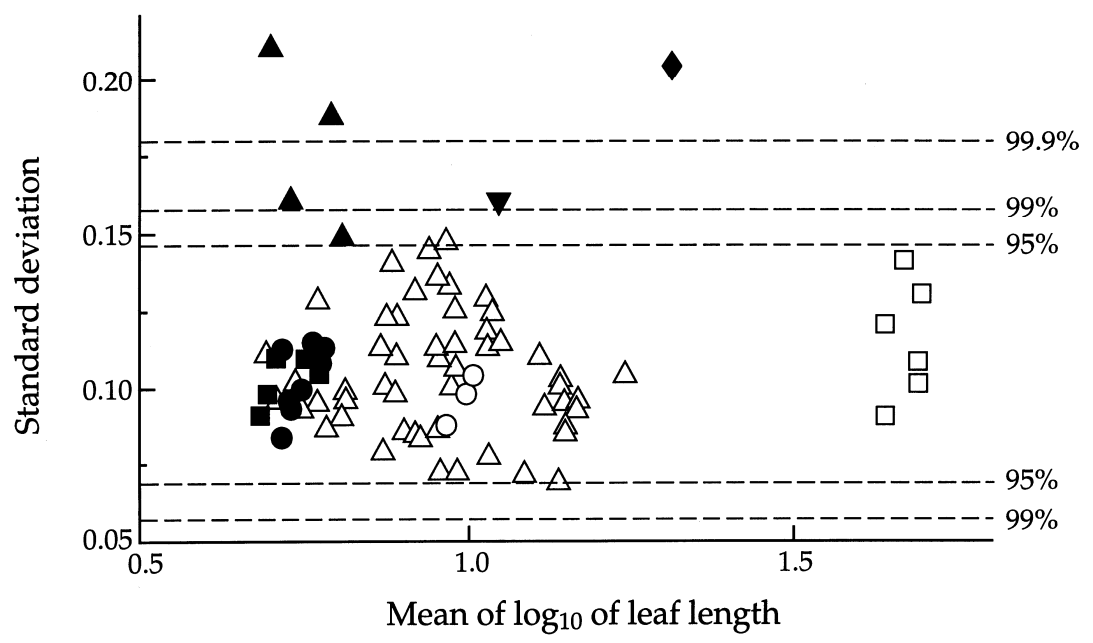

Figure 2. Standard deviations versus means of log transformed leaf lengths of fossil and extant forest floor litter samples of Nothofagus subgenus Lophozonia. Symbols for fossil the samples are Regatta Point (black triangles), Monpeelyata (inverted black triangle) and Pioneer (black diamond), Regency (black circles) and Langdon River (black squares). Symbols for the modern samples follow Fig. 1. The broken lines indicate confidence intervals for standard deviations of modern Nothofagus cunninghamii samples based on two tailed t-tests.

Representative distributions of transformed leaf lengths from extant samples are illustrated in Figure 3, and the results of distributional analyses are shown in Table 2. Most of the extant $N$. cunninghamii forest floor samples did not differ significantly from normal 
distributions (e.g. Fig. 3b), but some were consistent with two component normal distributions (e.g. Fig. 3c) and one (Fig. 3d) was consistent with three normal distributions. In each sample where a mixture of distributions was indicated, the standard deviation of at least one of the component distributions fell outside the $99 \%$ range for litter samples, and the combined standard deviation fell within this range. In most cases, the standard errors of the estimated component means overlapped, indicating that the distributions differed in variances rather than means. Bimodality in extant samples may be the result of two or three morphologically distinct trees dominating the sample. In some cases the distributions were significantly non-normal but unimodal. The $N$. moorei samples showed distinctly bimodal distributions (Fig. 3a, Table 2), with larger leaves forming the major (70 - 80 \%) size class but overall they were no more variable than N. cunninghamii.

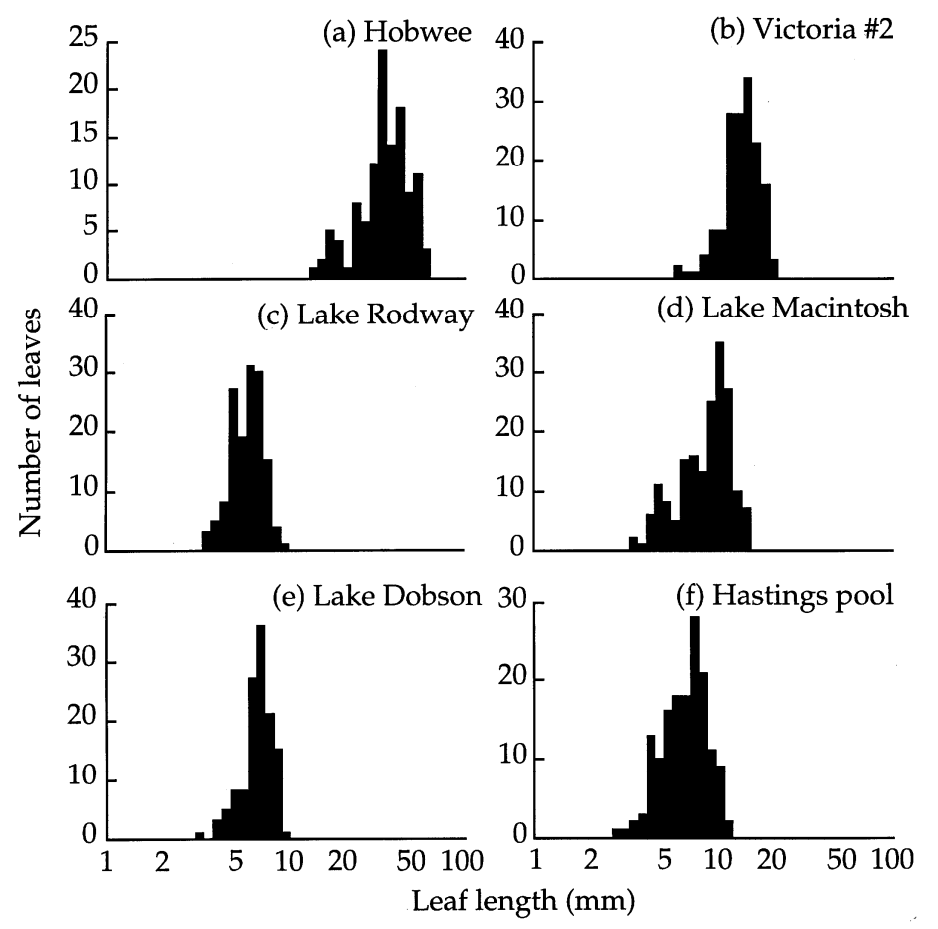

Figure 3. Leaf lengths of representative samples from forest floor litter (a-d) and recent lake sediments (e \& f). a. Nothofagus moorei. b-f. Nothofagus cunninghamii.

\section{Taphonomic analysis}

There was no evidence that sedimentary processes produce other than unimodal distributions of transformed $N$. cunninghamii leaf lengths (Table 1, Figs. 3e, f). The variability of transformed leaf length in the sediments was greater than that from the source vegetations in some case, but less in others (Fig. 4b).

The leaves from lake and drift sediments were significantly shorter than those from the forest floor of the source vegetations (Fig. 4a). Leaves in the river-carried samples were longer than those from the source vegetation litter in three out of four cases (Fig. 4a). The mean differences (litter - sediment) ranged from $0.04 \log _{10} \mathrm{~mm}$ to $0.13 \log _{10} \mathrm{~mm}$ for lakes, and from -0.06 to 0.05 for rivers. Taphonomic biases favouring shorter leaves are common in water transported sediments, but not universal (Spicer 1981). The lake samples are probably more similar to sites of fossilisation than the river samples, since the river samples appeared to be short lived sites of deposition, and fossils are generally derived from longer lived still bodies of water. Since the sites were chosen to represent a wide range of sedimentary environments, it is inferred that biases in transformed leaf lengths of $N$. cunninghamii in sediments lie in a range of about -0.05 to $0.15 \log _{10} \mathrm{~mm}$. 
Table 2. Distributional analysis of transformed leaf lengths of representative extant samples of Nothofagus subgenus Lophozonia. The component distributions are derived from MacDonald and Green (1988).

Estimates and standard errors of means, standard deviations and proportions of the total number of leaves are given for each component distribution. $c^{2}$ values are given for the goodness of fit of the final model, and for the improvement in fit obtained by fitting this model rather than one with only one distribution.

\begin{tabular}{|c|c|c|c|c|c|c|c|}
\hline \multirow[t]{2}{*}{ Sample } & \multirow{2}{*}{$\begin{array}{l}\text { Number } \\
\text { of leaves }\end{array}$} & \multicolumn{4}{|c|}{----------- Component distributions ----------- } & \multirow{2}{*}{$\begin{array}{c}c^{2} \\
\text { model } \\
(\mathrm{df})\end{array}$} & \multirow{2}{*}{$\begin{array}{c}\mathrm{c}^{2} \\
\text { gain } \\
(\mathrm{df}=3)\end{array}$} \\
\hline & & Number & Mean & $\begin{array}{l}\text { Standard } \\
\text { deviation }\end{array}$ & $\begin{array}{l}\% \text { of } \\
\text { total }\end{array}$ & & \\
\hline \multicolumn{8}{|c|}{ Nothofagus menziesii forest floor litter } \\
\hline Mt Cargill & 151 & 1 & $0.98 \pm 0.01$ & $0.10 \pm 0.01$ & 100 & $3.2(8) \mathrm{NS}$ & - \\
\hline Waiporo Gorge & 161 & 1 & $1.00 \pm 0.01$ & $0.11 \pm 0.01$ & 100 & 8.5 (8) NS & - \\
\hline \multicolumn{8}{|c|}{ Nothofagus moorei forest floor litter } \\
\hline \multirow[t]{2}{*}{ Mt Allyn } & 115 & 2 & $1.48 \pm 0.03$ & $0.08 \pm 0.03$ & $29 \pm 8$ & $7.2(6) \mathrm{NS}$ & $19 * * *$ \\
\hline & & & $1.73 \pm 0.01$ & $0.07 \pm 0.02$ & $71 \pm 8$ & & \\
\hline \multirow[t]{2}{*}{ Mt Hobwee } & 118 & 2 & $1.26 \pm 0.02$ & $0.04 \pm 0.02$ & $8 \pm 3$ & 9.9 (6) NS & $8.7 *$ \\
\hline & & & $1.60 \pm 0.02$ & $0.12 \pm 0.02$ & $92 \pm 3$ & & \\
\hline \multicolumn{8}{|c|}{ Nothofagus cunninghamii (Victoria) forest floor litter } \\
\hline Victoria \#1 & 156 & 1 & $1.18 \pm 0.01$ & $0.11 \pm 0.01$ & 100 & 6.7 (7) NS & - \\
\hline Victoria \#2 & 124 & 1 & $1.06 \pm 0.01$ & $0.10 \pm 0.01$ & 100 & $9.0(5) \mathrm{NS}$ & - \\
\hline \multicolumn{8}{|c|}{ Nothofagus cunninghamii (Tasmania) forest floor litter } \\
\hline Lake Rodway & 143 & 1 & $0.79 \pm 0.01$ & $0.09 \pm 0.01$ & 100 & $9.0(5) \mathrm{NS}$ & - \\
\hline \multirow[t]{3}{*}{ Lake Macintosh } & 110 & 3 & $0.71 \pm 0.01$ & $0.05 \pm 0.01$ & $16 \pm 3$ & 0.07 (3) NS & $27 * * *$ \\
\hline & & & $0.88 \pm 0.01$ & $0.04 \pm 0.01$ & $20 \pm 6$ & & $(\mathrm{df}=6)$ \\
\hline & & & $1.05 \pm 0.01$ & $0.06 \pm 0.01$ & $64 \pm 6$ & & \\
\hline Mt Michael & 120 & 1 & $0.89 \pm 0.01$ & $0.14 \pm 0.01$ & 100 & $11(8) \mathrm{NS}$ & - \\
\hline \multirow[t]{2}{*}{ Narcissus } & 108 & 2 & $0.71 \pm 0.02$ & $0.01 \pm 0.01$ & $6 \pm 2$ & 6.6 (4) NS & $23 * * *$ \\
\hline & & & $0.99 \pm 0.01$ & $0.08 \pm 0.01$ & $94 \pm 2$ & & \\
\hline LakeDobson & 90 & 1 & $0.93 \pm 0.02$ & $0.10 \pm 0.02$ & 100 & $10(4) *$ & - \\
\hline Farmhouse Creek & 121 & 1 & $0.85 \pm 0.01$ & $0.11 \pm 0.01$ & 100 & 6.3 (7) NS & - \\
\hline Hastings Pool & 167 & 1 & $0.85 \pm 0.02$ & $0.14 \pm 0.02$ & 100 & $10.3(6) \mathrm{NS}$ & - \\
\hline \multicolumn{8}{|c|}{ Nothofagus cunninghamii from recent aquatic sediment } \\
\hline Lake Dobson 2/5 & 125 & 1 & $0.85 \pm 0.01$ & $0.100 \pm 0.01$ & 100 & 11.89 (6) NS & - \\
\hline Lake Dobson $2 / 6$ & 101 & 1 & $0.87 \pm 0.02$ & $0.11 \pm 0.02$ & 100 & 9.13 (4) NS & - \\
\hline Hastings Pool & 153 & 1 & $0.86 \pm 0.02$ & $0.14 \pm 0.01$ & 100 & 7.93 (6) NS & - \\
\hline Macquarie Harbour & Ir 149 & 1 & $1.02 \pm 0.02$ & $0.12 \pm 0.14$ & 100 & $7.3(6) \mathrm{NS}$ & - \\
\hline Farmhouse Creek & 161 & 1 & $0.91 \pm 0.01$ & $0.080 \pm 0.01$ & 100 & $2.56(5) \mathrm{NS}$ & - \\
\hline
\end{tabular}

Climatic analysis of extant litter samples

Climatic parameters of BIOCLIM could explain $86.5 \%$ of the variation in transformed leaf length of $N$. cunninghamii leaf litter with the strongest correlated being mean temperature of the warmest quarter (summer temperature; accounting for $71.1 \%$, that is $r^{2}=0.711$ ). An additional $7.4 \%$ could be explained by adding mean temperature of the coldest quarter and a further $2.5 \%$ by adding rainfall of the wettest month. The contributions made by these additional parameters may not be significant since adding explanatory variables to a multiple regression increases the proportion of variation whether there is a causal relationship or not (Sokal and Rohlf 1981). The regression of summer temperature on transformed leaf length was linear.

Summer temperature is also the BIOCLIM parameter most strongly correlated with log transformed leaf lengths of litter of whole floras from a wider range of wet climates (G. J. Jordan unpublished). Summer is likely to be the period of optimum production for the evergreen species of Nothofagus subgenus Lophozonia, because winter temperatures are low, and summer water availability is relatively high where they live, and these species have optimum temperatures of acclimation for photosynthesis $\left(17-23{ }^{\circ} \mathrm{C}\right.$; Read 1990) which are more consistent with summer temperatures than winter temperatures. Thus summer 
temperature is likely to be a strong, if not the strongest, climatic determinant of leaf-size in $N$. cunninghamii. We will use it as an approximate estimator of relative past climates.
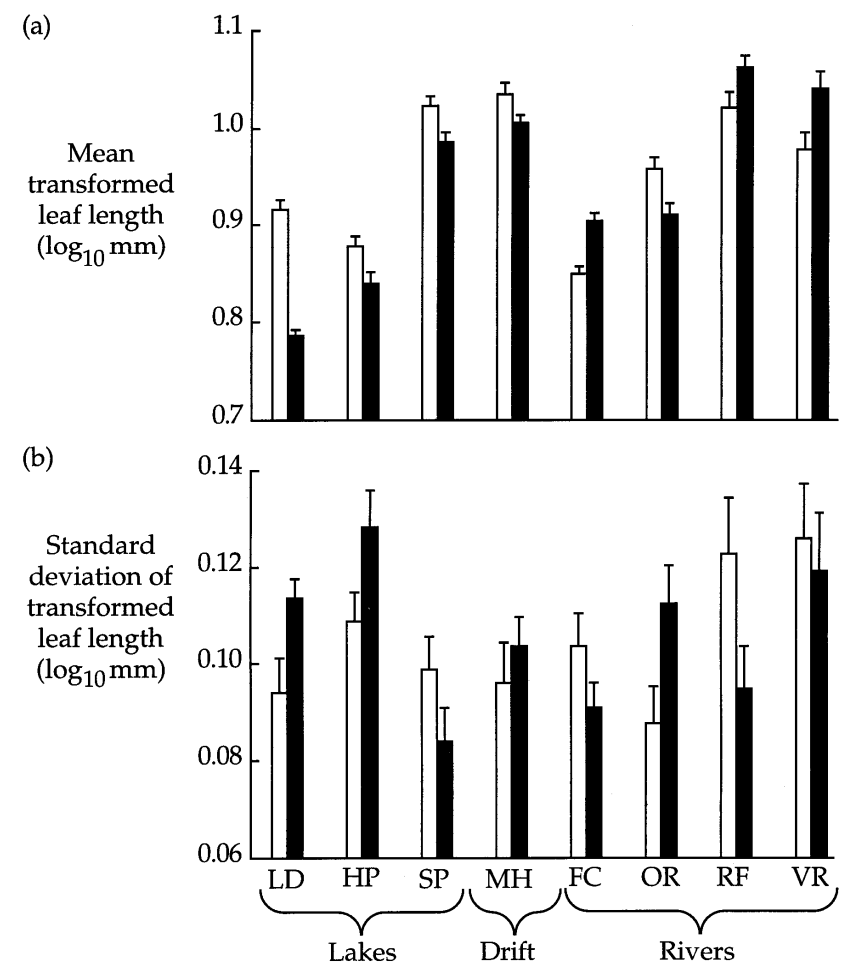

Figure 4. Means (a) and standard deviations (b) with standard errors of transformed leaf lengths of Nothofagus cunninghamii from recent aquatic sediment samples (black) and from forest floor litter samples from the local (or source) vegetation (white). The sites: $\mathrm{LD}=$ Lake Dobson, HP = Hastings Pool, SP = Shirleys Pool , MH = Macquarie Harbour, FC = Farmhouse Creek, OR = Old River, RF = Russell Falls, VR = Vale River.

Figure 5 shows the relationship of transformed leaf length to summer temperature. Transformed leaf length in N. moorei was not significantly correlated with any of the BIOCLIM parameters because there was little variation between the samples, in spite of being from a wide range of climates. However, the mean transformed leaf lengths of most of the $N$. moorei samples was greater than those of $N$. cunninghamii samples from similar summer temperatures. One of the N. menziesii samples had considerably lower mean of transformed leaf length than $N$. cunninghamii samples from locations with similar mean summer temperatures, but the other two samples were consistent with $N$. cunninghamii. This variation may be due to the relatively inaccurate method of estimating the temperatures

\section{Analysis of distributions of leaf lengths of fossil samples}

The means and standard deviations of transformed leaf lengths in the Regency and Langdon River fossil samples were consistent with extant N. cunninghamii (Fig. 2), but the means were close to the low end of the range even allowing for a large bias (e.g. $0.15 \log _{10} \mathrm{~mm}$ ). They showed unimodal distributions (Table 3; Fig. 6).

The means of transformed lengths of fossil leaves from Regatta Point were similar to extant $N$. cunninghamii but the standard deviations were greater (Fig. 2). RPU1 had a standard deviation about 1.5 times as large as any single extant sample and was strongly bimodal, with little overlap of the peaks (Table 3; Fig. 7 a). The standard deviations of the RPU2 samples were also high, with only the $17 \mathrm{~cm}$ sample falling within the $95 \%$ range of the extant samples. The $5 \mathrm{~cm}$ samples were highly significantly bimodal (Table 3; Fig. $7 \mathrm{~b}$ ), although the peaks overlapped more than in RPU1. The $17 \mathrm{~cm}$ sample was significantly bimodal, but the overlap was greater again (Table 3; Fig. $7 \mathrm{c}$ ). The $26 \mathrm{~cm}$ sample showed no 
significant bimodality (Table 3; Fig. 7 d). The standard deviations of each of the component distributions of the Regatta Point samples fell well within the range of extant samples, except for one component of the RPU2 $17 \mathrm{~cm}$ layer (0.043), but there was considerable uncertainty in this estimate.

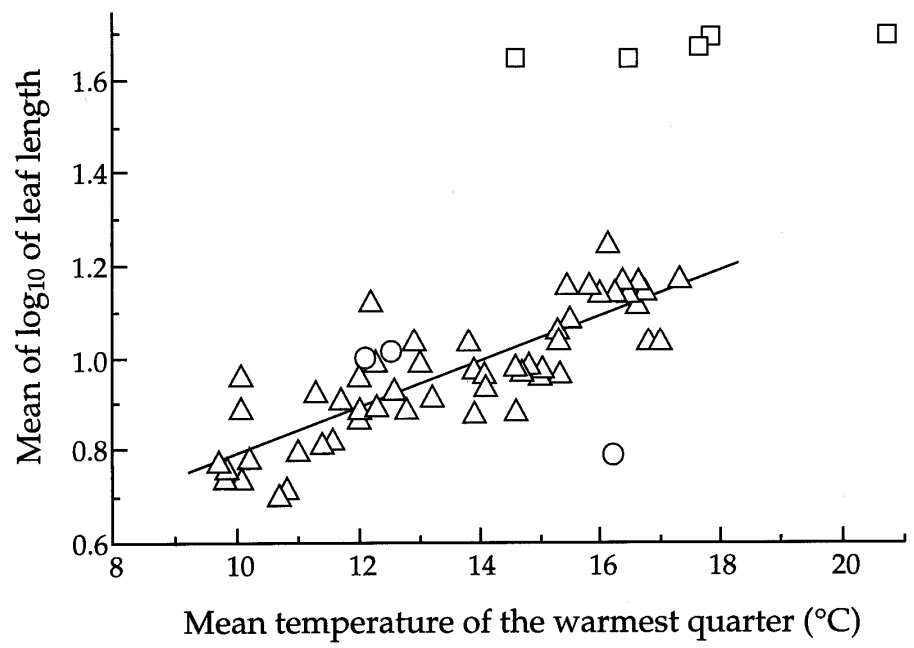

Figure 5. Means of transformed leaf lengths from extant forest floor leaf litter samples versus BIOCLIM estimates of the summer temperature for Nothofagus cunninghamii (triangles), Nothofagus moorei (squares) and Nothofagus menziesii (circles). The regression through the $N$. cunninghamii samples is: $\log 10($ length $)=0.2979$ + 0.0497 TWQ; where TWQ = temperature of the warmest quarter.

Table 3. Distributional analysis of transformed leaf lengths of representative fossil samples of Nothofagus subgenus Lophozonia. See caption for Table 2 for an explanation of headings.

\begin{tabular}{|c|c|c|c|c|c|c|c|c|}
\hline \multirow[t]{2}{*}{ Sample } & & \multirow{2}{*}{$\begin{array}{c}\text { Total } \\
\text { number } \\
\text { of leaves }\end{array}$} & \multicolumn{4}{|c|}{------- Component distributions --------- } & \multirow{2}{*}{$\begin{array}{c}\mathrm{c}^{2} \\
\text { model } \\
(\mathrm{df})\end{array}$} & \multirow{2}{*}{$\begin{array}{c}c^{2} \\
\text { gain } \\
(\mathrm{df}=3)\end{array}$} \\
\hline & & & imber & Mean & $\begin{array}{l}\text { Standard } \\
\text { deviation }\end{array}$ & $\begin{array}{l}\% \text { of } \\
\text { total } \\
\end{array}$ & & \\
\hline \multirow[t]{2}{*}{ Langdon River } & $285 \mathrm{~cm}$ & 72 & 1 & $0.72 \pm 0.03$ & $0.15 \pm 0.04$ & 100 & $8.1(5) \mathrm{NS}$ & - \\
\hline & $275 \mathrm{~cm}$ & 166 & 1 & $0.69 \pm 0.01$ & $0.09 \pm 0.01$ & 100 & $4.4(5) \mathrm{NS}$ & - \\
\hline \multirow[t]{6}{*}{ Regency } & $20 \mathrm{~cm}$ & 142 & 1 & $0.79 \pm 0.01$ & $0.12 \pm 0.01$ & 100 & $11(9) \mathrm{NS}$ & - \\
\hline & $30 \mathrm{~cm}$ & 49 & 1 & $0.79 \pm 0.02$ & $0.11 \pm 0.02$ & 100 & $9.0(7) \mathrm{NS}$ & - \\
\hline & $50 \mathrm{~cm}$ & 75 & 1 & $0.71 \pm 0.01$ & $0.08 \pm 0.01$ & 100 & $5.1(5) \mathrm{NS}$ & - \\
\hline & $60 \mathrm{~cm}$ & 186 & 1 & $0.72 \pm 0.01$ & $0.09 \pm 0.01$ & 100 & $10(5) \mathrm{NS}$ & - \\
\hline & $70 \mathrm{~cm}$ & 52 & 1 & $0.73 \pm 0.02$ & $0.13 \pm 0.02$ & 100 & 3.5 (6) NS & - \\
\hline & $80 \mathrm{~cm}$ & 160 & 1 & $0.72 \pm 0.01$ & $0.10 \pm 0.01$ & 100 & $15(6) *$ & - \\
\hline \multirow[t]{2}{*}{ RPU1 } & & 310 & 2 & $0.63 \pm 0.01$ & $0.12 \pm 0.01$ & $86 \pm 2$ & 25 (14) NS & $104 * * *$ \\
\hline & & & & $1.11 \pm 0.01$ & $0.07 \pm 0.01$ & $14 \pm 2$ & & \\
\hline \multirow[t]{5}{*}{ RPU2 } & $5 \mathrm{~cm}$ & 102 & 2 & $0.74 \pm 0.02$ & $0.13 \pm 0.02$ & $85 \pm 10$ & 14 (10) NS & $17 * * *$ \\
\hline & & & & $1.17 \pm 0.06$ & $0.08 \pm 0.07$ & $15 \pm 10$ & & \\
\hline & $17 \mathrm{~cm}$ & 143 & 2 & $0.76 \pm 0.01$ & $0.11 \pm 0.01$ & $89 \pm 4$ & $7.2(7) \mathrm{NS}$ & $8.6 *$ \\
\hline & & & & $1.06 \pm 0.02$ & $0.04 \pm 0.02$ & $11 \pm 4$ & & \\
\hline & $26 \mathrm{~cm}$ & 139 & 1 & $0.72 \pm 0.02$ & $0.16 \pm 0.01$ & 100 & 15 (11) NS & - \\
\hline Monpeelyata & & 48 & 1 & $1.06 \pm 0.02$ & $0.14 \pm 0.02$ & 100 & 6.9 (4) NS & - \\
\hline \multirow[t]{2}{*}{ Pioneer } & & 165 & 2 & $1.27 \pm 0.01$ & $0.19 \pm 0.03$ & $86 \pm 6$ & 17 (14) NS & $19 * * *$ \\
\hline & & & & $1.56 \pm 0.01$ & $0.03 \pm 0.01$ & $14 \pm 6$ & & \\
\hline
\end{tabular}




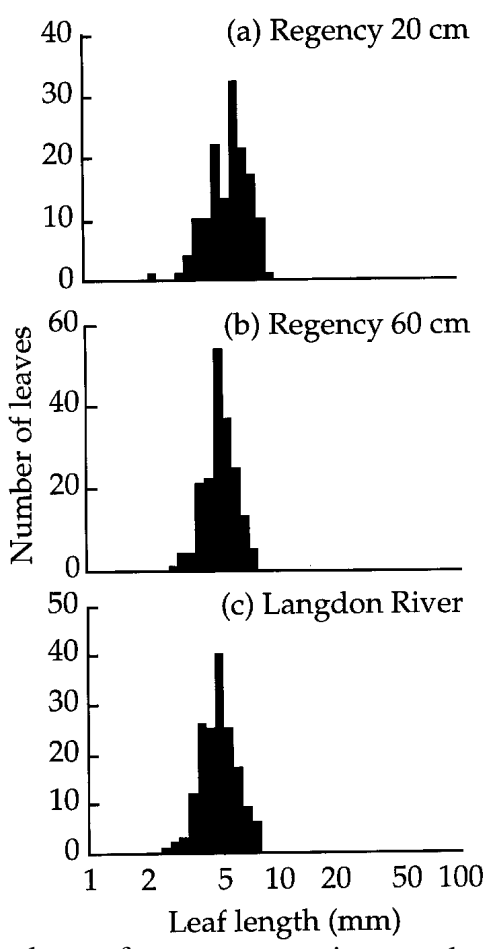

Figure 6. Lengths of fossil Nothofagus leaves from representative samples from Late Pleistocene sediments. a \& b Regency. c. Langdon River.

The standard deviations of transformed leaf lengths in the Pioneer sediments were considerably greater and those from Monpeelyata were slightly greater than any of the modern samples (Table 3; Fig. 2). Like the Regatta Point samples, the Pioneer sample was significantly bimodal, with most leaves being short. The Monpeelyata sample may have been too small to detect bimodality. The mean transformed leaf length at Pioneer was lower than extant $N$. moorei but leaf lengths ranged between those of extant $N$. cunninghamii and of extant $N$. moorei. The fossil leaves from Monpeelyata tended to be smaller than those from Pioneer, but were longer (on average) than any N. cunninghamii sample, although many leaves fell within the range of $N$. cunninghamii.

Figure 8 shows the changes in mean transformed leaf lengths between the strata of the Regency, Langdon River and Regatta Point sediments. Leaf length increased significantly ( $p$ $<0.01$ ) in the Regency sediments between $50 \mathrm{~cm}$ and $30 \mathrm{~cm}$ (Fig. 8a), but this increase (about $0.07 \log _{10} \mathrm{~mm}$ ) was smaller than the range in taphonomic biases found for recent $N$. cunninghamii leaves (up to about $0.21 \log _{10} \mathrm{~mm}$ ) and the range between modern sites with similar climates (about $0.25 \log _{10} \mathrm{~mm}$, Fig. 5). The leaves from below $50 \mathrm{~cm}$ depth were significantly shorter than those from $30 \mathrm{~cm}$ depth $(\mathrm{p}<0.05)$, with those from $40 \mathrm{~cm}$ intermediate. The strata from $20 \mathrm{~cm}$ and above also had larger leaves than the sediments below $40 \mathrm{~cm}$, but comparisons were difficult because the depositional environment apparently changed between 20 and $30 \mathrm{~cm}$.

There was a trend for the leaves in the Langdon River sediments to become shorter (Fig. $8 b)$. The leaves in the three youngest samples $(265-285 \mathrm{~cm})$ were all significantly shorter than those in the next oldest sample $(295 \mathrm{~cm})(\mathrm{p}<0.05)$. The oldest sample $(305 \mathrm{~cm}) \mathrm{had}$ relatively long leaves, but the small sample size hampered comparisons. The differences $(<$ $0.085 \log _{10} \mathrm{~mm}$ ) were slightly larger than those found in the Regency sediments. 

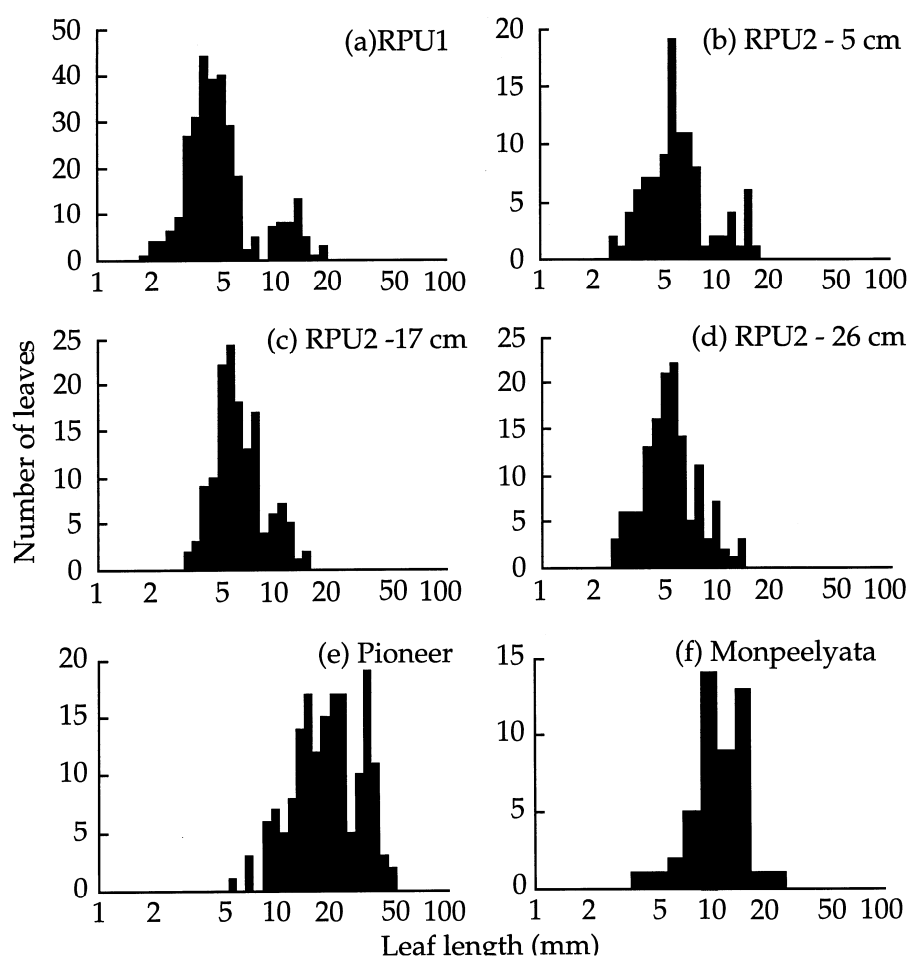

Figure 7. Lengths of fossil Nothofagus leaves from Tertiary and Early Pleistocene sediments. a-d. Regatta Point. e. Pioneer. f. Monpeelyata.

(a) Regency

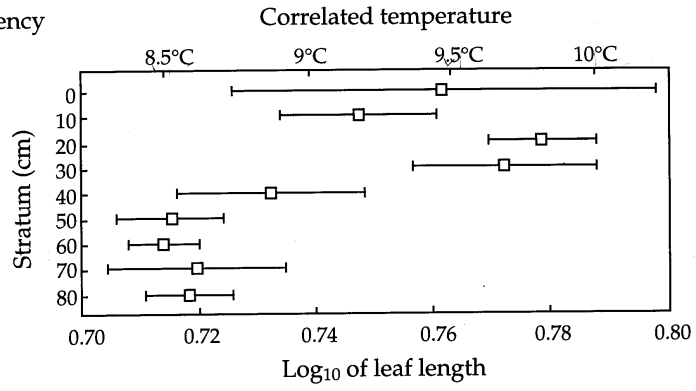

(b) Langdon River Correlated temperature
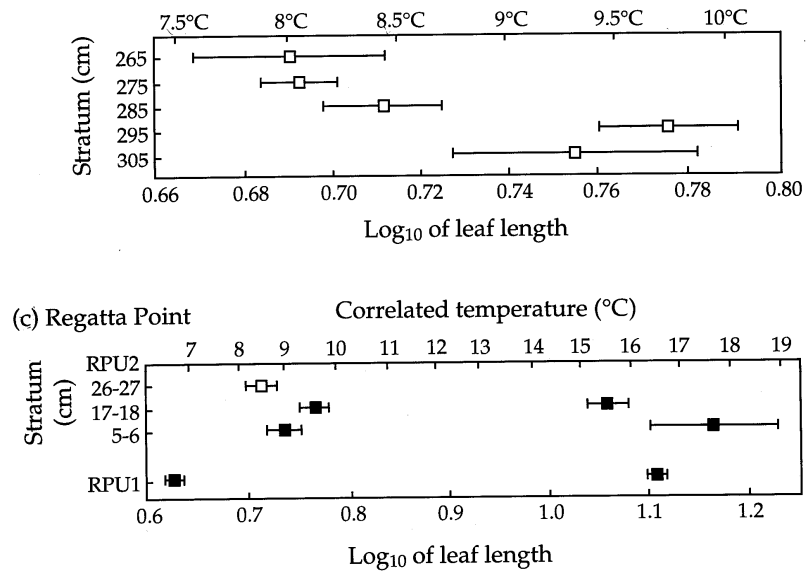

Figure 8. Means and standard errors of $\log _{10}$ leaf lengths of fossil Nothofagus leaves. a. Regency Formation. b. Langdon River. c. Regatta Point. Values for RPU1, and the 5-6 and 17-18 cm strata of RPU2 are estimates for the component distributions. 


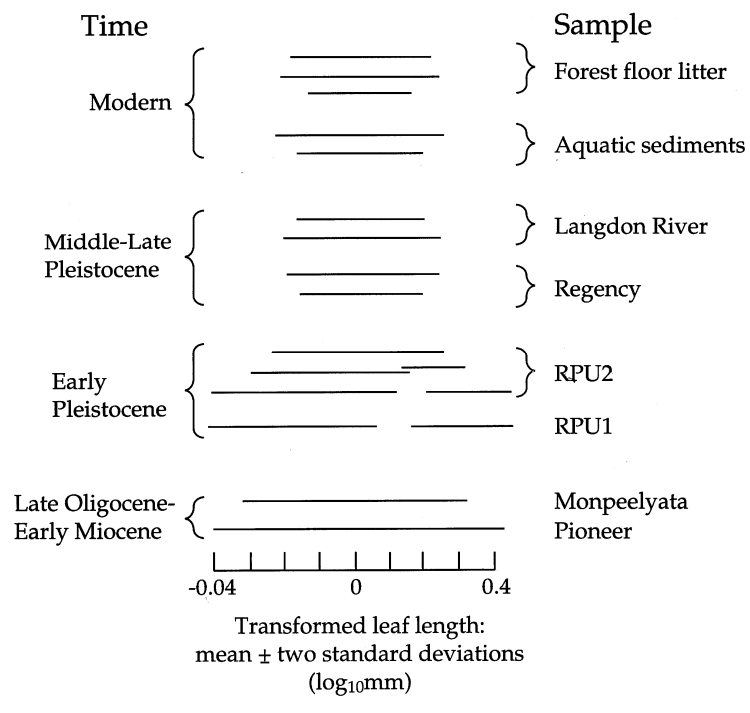

Figure 9. Variability in leaf lengths of representative samples of Nothofagus subgenus Lophozonia leaves through time. Bars $=$ mean $\log _{10}$ leaf length \pm two standard errors.

\section{Discussion}

Variation in modern samples

The results presented here confirm that summer temperature, or a close correlate, is a very strong determinator of mean transformed leaf length in $N$. cunninghamii. The remainder of the variation in mean transformed leaf length among sites from apparently similar climates (Fig. 5) may have arisen from unrepresentative sampling, from responses to other environmental factors, from historical effects, or from inaccuracy in the BIOCLIM estimates. Other environmental factors include other climatic factors, biotic and edaphic factors. Historical effects include genetic isolation making leaf size reflect past conditions.

Figure 5 shows that $N$. moore $i$ has longer leaves than $N$. cunninghamii from climates with similar summer temperatures, and which vary little in mean transformed leaf length between sites. This is probably due to differences in preferences between species, although other past and present environmental effects may partly determine these differences (Read and Hope 1989). The small variability between populations of $N$. moorei suggests there is little genetic variability between populations, which together with its apparently conservative physiology (Read, Hope \& Hill 1988) suggests that its ecological range has been severely restricted, perhaps due to cold and dry periods during the Pleistocene, or competition from warm temperate species (Read and Hope 1989).

Regency

Both the micro- and macrofossil floristics of the Regency sediments changed between $40 \mathrm{~cm}$ and $30 \mathrm{~cm}$ (Fitzsimons et al. 1990) during approximately the same period as the increase in leaf size. Thus, both leaf length and floristics appear to have responded to similar environmental changes. The increase in leaf length was unlikely to have been solely the result of changes in the depositional environment, since marked differences in preservation occurred independently of the change in leaf length (very well preserved, well preserved and poorly preserved strata each occur both above and below the $40 \mathrm{~cm}$ stratum). Changes in the depositional environment are not sufficient to explain the floristic changes, since the changes in the micro- and macrofossils floras were similar and included both the loss and gain of common species. 
Both the floristic changes and the changes in leaf length are consistent with increased temperature (Fitzsimons et al. 1990; Jordan 1992). The changes in leaf size were small, equivalent to a difference in modern sites of less than about $1.5^{\circ} \mathrm{C}$ (Fig. 8a) but the floristic changes indicated a larger temperature differential. Before the change in leaf size the floristics were similar to modern subalpine vegetation and after the change they were similar to modern lowland vegetation. This change is equivalent to a modern altitude difference of about 300$900 \mathrm{~m}$ and, hence, a change in summer temperature of about $2-6{ }^{\circ} \mathrm{C}$, assuming a lapse rate of $0.65^{\circ} \mathrm{C}$ per $100 \mathrm{~m}$ (derived from BIOCLIM).

These changes in leaf sizes may have arisen either through the same tree producing leaves of different sizes (phenotypic plasticity), through selection acting within populations, or through selection acting on new genetic material (seed or pollen from genetically distinct populations). Leaf size in modern $N$. cunninghamii appears to show only moderate phenotypic plasticity (Hill \& Read 1987). Variation in leaf morphology between trees within populations appears to be small, suggesting the genetic diversity within extant populations is limited, although some of the variation may be hidden by heterozygosity and selection. Large changes in morphology in response to climate change are, therefore, most likely to occur with the inflow of genes from other areas. Thus, the small, but significant, changes in leaf length in the Regency population of $N$. cunninghamii suggest that these were responses to climatic changes, but were limited by available genetic variability and phenetic plasticity.

\section{Langdon River}

The changes in transformed Nothofagus leaf length in the Langdon River sediments were greater than those in the Regency sediments even though the associated floristic changes were considerably less marked. The abundance of sclerophyllous taxa increased slightly which is typical of the early part of the transition from interglacial to glacial conditions (e.g. Colhoun 1988). Marked floristic changes clearly indicating a transition from interglacial to glacial conditions occurred later. Thus, the decrease in leaf length may have been an early response to cooling before the main floristic change. Such a rapid change may have resulted from phenetic plasticity, and/or from selection within the population. Although there was no evidence of change in depositional environment (Colhoun et al. 1989), a taphonomic cause cannot be excluded since the changes $\left(<0.085 \log _{10} \mathrm{~mm}\right)$ are well within the range of taphonomic biases (about $0.21 \log _{10} \mathrm{~mm}$ ).

\section{Regatta Point sediments}

The Regatta Point samples are generally more variable than extant populations of $N$. cunninghamii (Fig. 2) and tend to show bimodal distributions of leaf lengths. The RPU2 samples appeared to form a continuum from the $5 \mathrm{~cm}$ sample which approached the RPU1 sample in bimodality, to the $26 \mathrm{~cm}$ sample, which was consistent with a derivation from two populations of similar leaf size, or a single population which was more variable than extant populations of $N$. cunninghamii (Fig. 8c). The high variability and bimodality of the RPU1 sample are unlikely to be due to its composite nature, because leaves from both extremes of this range often occurred together within strata.

The leaves from the bimodal Regatta Point samples were consistent with a derivation from the equivalent of two distinct extant populations of $N$. cunninghamii, one adapted to subalpine-alpine conditions, and another adapted to conditions at least as warm as lowland western Tasmania today (see Fig. 8c). The differences between the means of the component distributions in these samples (up to $0.48 \log _{10} \mathrm{~mm}$ ) tended to be too large to be explained by taphonomic processes (up to $0.21 \log _{10} \mathrm{~mm}$ ).

Thus, two different leaf forms of Nothofagus subgenus Lophozonia almost certainly occurred in the catchment of the sediments through the presence of (1) a species with highly variable, bimodal leaf size distributions, (2) two species with different leaf lengths or (3) two geographically disjunct populations of markedly different leaf size. This situation persisted 
for a relatively long time, since it occurs in both the RPU2 and RPU1 sediments, which are unlikely to have been deposited at the same time since they are floristically different. Each of these possibilities will now be considered.

(1) The hypothesis of populations with variable, bimodally distributed leaf lengths is consistent with available data. Although modern populations of $N$. cunninghamii do not show bimodal leaf length distributions, modern populations of $N$. moorei and the fossils from Pioneer do. The cause of bimodality of the fossil samples is unlikely to be the same as in $N$. moorei (small leaves produced at the beginning of the growth season and on flowering branches; Hill 1983a) because, unlike the $N$. moorei samples, the smaller leaved size classes in the fossil samples contain more leaves than the large leaved size classes. It is possible that the bimodality was a response to conditions no longer present in the range of $N$. cunninghamii, and leaf length in modern populations may become bimodal under suitable conditions. However, the presence of other highly variable taxa in the Regatta Point sediments is also consistent with greater than modern variability within species at this site. In particular, Telopea leaves from the sediments show far greater variability in cuticular morphology than modern species of the genus (Jordan 1992). This variability appears to be continuous and cannot be readily attributed to the presence of several species. Pollen of Lagarostrobos (Phyllocladidites mawsonii) from the sediments is also more variable than pollen of extant Lagarostrobos in Tasmania, although this may be due to the presence of extinct species (Macphail et al. 1993b).

(2) The hypothesis of the co-occurrence of two species of Nothofagus subgenus Lophozonia is also consistent with the floristics of the Regatta Point sediments. These imply that the catchment contained both modern and extinct species (Jordan 1992, Macphail et al. 1993b). Although leaf lengths of different species of Nothofagus subgenus Lophozonia may be different under similar climates (Fig. 2) a large leaved species would probably have had general preferences for warmer climates than the small leaved species. The co-occurrence of congeneric species of woody plants whose leaf forms differ primarily in size is common in Tasmania. Where there is relatively abundant water, the smaller leaved species tend to have distributions indicating general preferences for colder climates than the larger leaved species. Some examples include (large leaved species first) Eucryphia lucida (Labill.) Baill. and E. milliganii Hook. f.; Cyathodes juniperina (Forst.) Druce and C. parvifolia R. Br.; Richea pandanifolia Hook. f. and $R$. scoparia Hook. f.; and $R$. dracophylla R. Br. and $R$. scoparia. The co-occurrence in the Regatta Point sediments of a cold climate species of Nothofagus with one adapted to moderate climates is consistent with floristic evidence for the cooccurrence of taxa with apparently contrasting thermal preferences (Jordan 1992, Macphail et al. 1993 b).

If two distinct species were present at Regatta Point then one is now extinct, and the other is probably ancestral to modern $N$. cunninghamii. The large fossils tend to be more ovate than most large leaved forms of modern $N$. cunninghamii. The other extinct taxa in the Regatta Point sediments mainly have living relatives in warmer climates than modern Tasmania. The small leaved form is, therefore, more likely to have been the ancestor of $N$. cunninghamii than the large leaved form.

(3) The hypothesis of geographically separated populations of differing leaf size is highly unlikely unless there was considerably greater local variation between populations at the time of deposition than now. The differences in sizes between the large and small leaves in the RPU1 sample is $0.48 \log _{10} \mathrm{~mm}$. The differences in the RPU2 samples are slightly smaller. These are large compared with the range between extant populations from similar climates (about $0.25 \log _{10} \mathrm{~mm}$ ) which is an overestimate for populations within a region, since much of this range is derived from differences between regions. Even allowing for the possible range in taphonomic bias $\left(0.15 \log _{10} \mathrm{~mm}\right)$, the difference between populations is inconsistent with modern populations derived from similar climates. The leaves in the sediments almost certainly came from plants growing in similar climates, since no point within $11 \mathrm{~km}$ of the 
sediments is over $350 \mathrm{~m}$ altitude and the region is tectonically and erosionally stable (Baillie 1989; E. A. Colhoun pers. comm.). The small leaved (cool climate) forms are much more common $(>80 \%)$ than the large leaved forms, and it is highly unlikely that they would be dominant after long distance transport, since proportions of leaves transported by rivers becomes diluted with distance (Spicer and Wolfe 1987).

Invasion of a small leaved form by a larger leaved form during a transition from glacial to interglacial conditions may have caused the trend of changing bimodality in the RPU2 sediments, although a taphonomic cause (where the larger leaved form is excluded by sorting) cannot be excluded. The mixture of cold and warm climate taxa in the Regatta Point sediments is consistent with this hypothesis. The change is less likely to represent a transition from interglacial to glacial conditions since these phases appear to have been generally slow (e.g. Shackleton \& Opdyke 1973).

\section{Monpeelyata and Pioneer}

The high variability in leaf lengths from Monpeelyata is likely to be the result of high variability in the local vegetation rather than taphonomic effects, since the sediments are homogeneous and suggest a low energy depositional environment (Macphail et al. 1991). Similarly, the Nothofagus leaves measured from the Pioneer sediments are from only one, relatively homogeneous lens, although they appear to be the result of a higher energy river system (Hill and Macphail 1983). A taphonomic cause for part of the high variability at Pioneer cannot, therefore, be excluded, but, like the leaves from RPU1, the variability is high compared to total range in modern species. The bimodality in leaf length may be due to the presence of more than one species, but there appears to be continuous variation in leaf shape, and no discrete differences in cuticular morphology, whereas the cuticles of extant species and other Tertiary species of Nothofagus are clearly distinct (Hill 1991; Hill \& Read 1991). Also, the estimated standard deviation $\left(0.189 \log _{10} \mathrm{~mm}\right)$ of one component of the Pioneer sample is greater than $99.9 \%$ of modern samples.

\section{General Discussion}

Clear trends in both the size and variability of transformed leaf lengths of fossil Nothofagus subgenus Lophozonia are apparent in these results (Fig. 9). The trend of decreasing leaf size in the subgenus discussed by Hill $(1983 a ; 1991)$ is supported by the data presented here. The Tertiary samples and Early Pleistocene samples are more variable than modern samples, whereas the Middle Pleistocene samples are consistent with modern aquatic and litter samples. The leaf lengths of another evergreen member of Nothofagus subgenus Lophozonia, $N$. tasmanica, from the Oligocene Cethana sediments in northern Tasmania, also appear to be highly variable, although it is difficult to make quantitative comparisons because these leaves occur only as impressions. In addition, Early Pleistocene and Tertiary fossils often show bimodal distributions, with more leaves in the smaller leaved size classes than in the large leaved size classes. The bimodality and elevated variability of leaf length are inconsistent with the variation of modern populations. Correlation of leaf length with modern climates, and the trends apparent in the Regency sediments, suggest that leaf length in N. cunninghamii is largely a function of summer temperature, but the full response of populations to climate may be delayed by a lack of local genetic variability. Leaf width showed similar general trends in variability and correlation with temperature as leaf length in both the extant and fossil samples except that the decrease in leaf width from Tertiary samples to Quaternary samples was relatively smaller than for leaf length.

Two possible explanations for these trends are (1) that it was not possible to distinguish between closely related Nothofagus species in the Monpeelyata sediments, and only possible to separate species in the Regatta Point and Pioneer sediments by using leaf size distributions for whole populations or (2) Tertiary populations of species were considerably more variable than modern populations, and often bimodal, and that variability had declined to modern levels by the Middle Pleistocene. Either explanation represents a decline in diversity, 
consistent with the general decline of rainforest diversity in western Tasmania during the end of the Tertiary and the Early and Middle Pleistocene (Jordan 1992; Carpenter et al. 1994; Macphail et al. 1993b).

Rapid and severe cycles in climate may have reduced the variability through the elimination of long leaved morphs by cold periods followed by the elimination of short leaved morphs by warm conditions However high variability may have selective advantages in variable conditions. Elevated variability within populations is certainly associated with recent mixing of genotypes (Endler 1977), which is a possible result of migration in response to climate change. This is a plausible explanation for the distributions found at Regatta Point which may well have been from a period of rapid environmental changes, causing the mixing of genotypes, but this explanation fails to explain elevated variability and bimodality in the Tertiary samples, unless the climate during the Oligocene/Miocene was highly variable. This is possible, since there is evidence for both temperate rainforest and glaciation at moderate altitudes during the Oligocene in Tasmania (Macphail et al. 1993a). The bimodality of the Regatta Point and Pioneer samples is inconsistent with modern population variation, since the small leaved size class is dominant in the fossils and in $N$. moorei the large size class is dominant. This can be explained by either the presence of more than one species, or by some unknown cause of bimodality in leaf form. Therefore, the most likely explanation of the discrepancies between the older fossil and the younger fossil and modern data is the presence of higher within population variation and bimodal leaf size distributions prior to the Middle Pleistocene, although the presence of cryptic species in fossil samples is an alternative.

The small change in leaf size apparent in the Regency deposit in response to apparently large climatic changes may indicate that there was relatively little external genetic input. The differences in the timing of changes in leaf form and in floristics seen in the Regency and Langdon River sediments may indicate ecological lag in floristics and/or leaf form.

Phenotypic plasticity within trees, the variability of the local gene pool, and time for invasion of new genes may each contribute some delay between climatic change and resulting morphological change. The first response lag will be the time of replacement of leaves, a few years. The second will be within generations (up to several hundred years each), depending on the strength of selection. The third lag will be greater, but will depend on the relative abundances of local and invading seed and pollen The main temperate and Boreal forest tree species of North America appear to show a lag time in floristics of a few hundred years behind the climate changes (e.g. Schoonmaker \& Foster 1991). However N. cunninghamii is a species with very wide ecological tolerances, and its resistance to change may be great.

Future research into the shapes of the fossil and living leaves and into the amount of the variation in leaf length due to genetic causes may shed light on the causes of the patterns of variation in the Tertiary and Pleistocene fossil leaves observed here.

\section{Acknowledgments}

The authors thank Brad Potts, Ray Carpenter, Matt McGlone, Jenny Read, Geoff Hope and Robert Wiltshire for help with this project, and comments on manuscripts, and Eric Colhoun for help with aging the sediments. GJJ received an Australian Postgraduate Research Award. A grant from the Australian Research Council supported this project.

\section{References}

Baillie PW. 1989. Jurassic-Cainozoic. In: Burrett CF, Martin EL, eds. Geology and Mineral Resources of Tasmania. Melbourne: Geological Society of Australia, 339-409.

Bowler JM. 1982. Aridity in the late Tertiary and Quaternary of Australia. In: Barker WR, Greenslade PJM, eds. Evolution of the Flora and Fauna of Arid Australia.. Adelaide: Peacock Publications, 35-46.

Burnham RJ. 1989. Relationships between standing vegetation and leaf litter in a paratropical forest: implications for paleobotany. Review of Palaeobotany and Palynology 58: 5-32. 
Busby JR. 1984. Nothofagus cunninghamii (Southern Beech) Vegetation in Australia. Australian Flora and Fauna Series. Number 1. Canberra: Australian Government Publishing Service.

Busby JR. 1988. Potential impacts of climate change on Australia's flora and fauna. In: Pearman GI, ed. Greenhouse: Planning for Climate Change. Melbourne: CSIRO, 387-398.

Carpenter RJ, Hill RS, Jordan GJ. 1994. Cenozoic vegetation in Tasmania: Macrofossil evidence. In: Hill RS, ed. History of Australian Vegetation Cretaceous to Recent, Cambridge: Cambridge University Press, 276-298.

Christophel DC, Greenwood DG. 1989. Changes in climate and vegetation in Australia during the Tertiary. Review of Palaeobotany and Palynology 58: 95-109.

Colhoun EA. 1988. Cainozoic vegetation of Tasmania. Department of Geography, University of Newcastle Special Paper.

Colhoun EA, van der Geer G, Hill RS, Bird T. 1989. Interglacial pollen and plant macrofossils from Langdon River, western Tasmania. New Phytologist 111: 531-548.

Endler JA. 1977. Geographical Variation, Speciation and Clines. Princeton: Princeton University Press.

Ferguson DK. 1985. The origin of leaf assemblages - new light on an old problem. Review of Palaeobotany and Palynology 46: 117-188.

Fitzsimons SJ, Colhoun EA. 1991. Pleistocene glaciation of the King Valley, western Tasmania, Australia. Quaternary Research 36: 135-156.

Fitzsimons SJ, Colhoun EA, van der Geer G, Hill RS. 1990. Definition and character of the Regency Interglacial and Early-Middle Pleistocene stratigraphy in the King Valley, western Tasmania, Australia. Boreas 19: 1-15.

Gentilli J. 1972. Australian Climatic Patterns. Melbourne: Nelson.

Givnish TJ. 1984. Leaf and canopy adaptions in tropical forests. In: Medina E, Mooney HA, Vasquez-Yanez C, eds. Physiological Ecology of Plants of the Wet Tropics. The Hague: Dr Junk, 51-84.

Givnish TJ. 1987. Comparative studies of leaf form: assessing the relative roles of selected pressures and phylogenetic constraints. New Phytologist 106: 131-161.

Harland WB, Armstrong RL, Cox AV, Craig LE, Smith AG, Smith DG. 1990. A Geologic Time Scale 1989. New York: Cambridge University Press.

Hill RS. 1983a. Evolution of Nothofagus cunninghamii and its relationship to N. moorei as inferred from Tasmanian macrofossils. Australian Journal of Botany 31: 453-465.

Hill RS. 1983b. Nothofagus macrofossils from the Tertiary of Tasmania. Alcheringa 7: 169183.

Hill RS. 1991. Tertiary Nothofagus (Fagaceae) macrofossils from Tasmania and Antarctica and their bearing on the evolution of the genus. Botanical Journal of the Linnean Society 105: $73-112$.

Hill RS, Gibson N. 1986. Distribution of potential macrofossils in Lake Dobson, Tasmania. Journal of Ecology 74: 373-384.

Hill RS, Jordan GJ. 1993. The evolutionary history of Nothofagus (Nothofagaceae). Australian Systematic Botany 6: 111-126.

Hill RS, Macphail MK. 1983. Reconstruction of the Oligocene vegetation at Pioneer, northeast Tasmania. Alcheringa 7: 281-299.

Hill RS, Macphail MK. 1985. A fossil flora from rafted Plio-Pleistocene mudstones at Regatta Point, Tasmania. Australian Journal of Botany 33: 497-517.

Hill RS, Read J. 1987. Endemism in Tasmanian cool temperate rainforest: alternative hypotheses. Botanical Journal of the Linnean Society 95: 113-124.

Hill RS, Read J. 1991. A revised infrageneric classification of Nothofagus (Fagaceae). Botanical Journal of the Linnean Society 105: 37-72.

Hope GS. 1994. Quaternary vegetation. In: Hill RS, ed. History of Australian Vegetation. Cretaceous to Recent. Cambridge: Cambridge University Press, 368-389. 
Jordan GJ. 1992. Macrofossil Evidence for Quaternary Plant Extinction and Vegetation Change in Western Tasmania. Ph.D. thesis, University of Tasmania, Australia.

Jordan GJ, Carpenter RJ, Hill RS. 1991. Late Pleistocene vegetation and climate near Melaleuca Inlet, south-western Tasmania. Australian Journal of Botany 39: 315-333.

Kershaw AP. 1988. Australasia. In: Huntley B Webb T III, eds. Vegetation History. Dordrecht: Klouwer Academic Publishers, 238-306.

Kershaw AP, D'Costa DM, McEwen Mason JRC, Wagstaff BE. 1991. Palynological evidence for Quaternary vegetation and environments of mainland southeastern Australia. Quaternary Science Reviews 10: 391-404.

MacDonald PDM, Green PEJ. 1988. User's guide to Program MIX. Hamilton Ontario: Icthus Data Systems.

Macphail MK, Alley N, Truswell EM, Sluiter IR. 1994 Early Tertiary vegetation. Evidence from spores and pollen. In: Hill RS, ed. History of Australian Vegetation. Cretaceous to Recent. Cambridge: Cambridge University Press, 189-261.

Macphail MK, Colhoun EA, Kiernan K, Hannan D. 1993a. Glacial climates in the Antarctic region during the late Paleogene: evidence from northwest Tasmania, Australia. Geology 21: 145-148.

Macphail MK, Hill RS, Forsyth SM, Wells PM. 1991. A Late Oligocene-Early Miocene cool climate flora in Tasmania. Alcheringa 15: 87-106.

Macphail MK, Jordan GJ, Hill RS. 1993b. Key periods in the evolution of the Tasmanian Cenozoic vegetation and flora. 1: The Early-Middle Pleistocene. Australian Journal of Botany 41: 637-707.

Macphail MK, Truswell EM. 1989. Palynostratigraphy of the west central Murray Basin. Bureau of Mineral Resources, Australia Record 1988/7: 115-120.

New Zealand Meteorological Service. 1963-1985. Meteorological Observations for stations in New Zealand and outlying stations in Cook Islands, Kingdom of Tonga, Western Samoa, Tokelau, Tuvalu, Kiribati, Nive Island, and Line Islands. Government Printer: Wellington.

Pole MS, Hill RS, Green N, Macphail MK. 1993. The Miocene Berwick Quarry flora rainforest in a drying climate. Australian Systematic Botany 6: 399-428.

Read J. 1990. Some effects of acclimation temperature on net photosynthesis in some tropical and extra-tropical Australasian Nothofagus species. Journal of Ecology. 78: 100112.

Read J, Busby JR. 1990. Comparative responses to temperature of the major canopy species of Tasmanian cool temperate rainforest and their ecological significance. II. Net photosynthesis and climate analysis. Australian Journal of Botany 38: 185-205.

Read J, Hope GS. 1989. Foliar frost resistance of some evergreen tropical and extratropical Australasian Nothofagus species. Australian Journal of Botany 37: 361-373.

Read J, Hope GS, Hill RS. 1988. Integrating historical and ecophysiological studies in Nothofagus to examine the factors shaping the development of cool temperate rainforest in southeastern Australia. Proceedings, 3rd Conference of the International Organisation of Palaeobotanists 97-106.

SAS Institute Inc. 1988. SAS/STAT User's Guide for Personal Computers, Release 6.03 Edition. Cary, N.C.: SAS Institute Inc.

Schoonmaker PK, Foster DR. 1991. Some implications of paleoecology for contemporary ecology. The Botanical Review 57: 204-245.

Shackleton NJ. 1982. The deep-sea sediment record of climate variability. Progress in Oceanography 11: 199-218.

Shackleton NJ, Opdyke ND. 1973. Oxygen isotope and palaeomagnetic stratigraphy of equatorial Pacific core V28-238: Oxygen isotope temperatures and ice volumes on a $10^{5}$ and $10^{6}$ year scale. Quaternary Research 3: 39-55.

Sokal RR, Rohlf FJ. 1981. Biometry. San Francisco: W. H. Freeman and Company. 
Spicer RA. 1981. The sorting and deposition of allochthonous plant material in a modern environment at Silwood Lake, Silwood Park, Berkshire. Geological Survey Special Paper 1143: $1-77$.

Spicer RA, Wolfe JA. 1987. Plant taphonomy of late Holocene deposits in Trinity (Clair Engle) Lake, northern California. Paleobiology 13: 227-45.

Webb LJ. 1959. A physiognomic classification of Australian rainforests. Journal of Ecology 47: 551-570.

Webb LJ. 1968. Environmental relationships of the structural types of Australian rain forest vegetation. Ecology 49: 296-311.

Wolfe JA, Upchurch GR. 1987. North American nonmarine climates and vegetation during the Late Cretaceous. Palaeogeography, Palaeoclimatology, Palaeoecology 61: 33-77. 